\title{
Students' Anxiety in Writing Introduction of Thesis Proposal at Universitas Muslim Nusantara Al- Washliyah Medan
}

\author{
Yulina Oktaviani Harahap ${ }^{1 *}$ and Hermawati Syarif ${ }^{2}$ \\ ${ }^{1}$ English Department, FBS Universitas Negeri Padang, Padang, Sumatra Barat 25131, Indonesia \\ ${ }^{2}$ English Department, FBS Universitas Negeri Padang, Padang, Sumatra Barat 25131, Indonesia \\ *Corresponding author. Email: yulinaoktaviani@gmail.com
}

\begin{abstract}
Writing is one of the skills in learning English that has to be mastered by students, especially at the tertiary level. Students are hoped to be able to write a thesis proposal, but anxiety obstructs students' thesis proposal writing. Anxiety is a psychological factor that can effected the students' troubles in writing a thesis. Based on the explanation above, this study had a goal to analyse students' anxiety in writing an introduction of thesis proposal. The anxienty levels, types and causes in writing of thesis proposal were examined. This study was descriptive research which aimed to describe and analyse the existed condition in the field. The subjects of the research were the students at Universitas Muslim Nusantara Al-Washliyah in academic year 2017/2018. The data was carried out through an e-questionnaire and interview. As a result of the study, students' anxiety in writing introduction of thesis proposal was identified and classified based on several indicators related to the levels (high, moderate, andlow), types (cognitive, somatic, and behaviour avoidance) and causes of anxiety (low self-confidence, self-perception, and lack of knowledge) in writing background of thesis proposal.
\end{abstract}

\section{Keywords: Anxiety, Introduction of Thesis Proposal, Writing}

\section{INTRODUCTION}

In the tertiary level, students have to master the writing skill in learning English. Universitas Muslim Nusantara Al-Washliyah Medan (UMN AW) is one of the tertiary levels which offer writing classes for its students. It is hoped the students are able to write a thesis proposal.

A thesis proposal is the foundation part of the process of thesis writing. It should be started with the introduction section. As the first part, the introduction plays an important role that contains all requirements which describe what a researcher will do in research and what she/he will produce.

However, the introduction part of the thesis proposal seems the most difficult part in writing a proposal for several students. Even if students learn the language for so many years, they still find it difficult to write. Along with, the students are caused by internal and external factors which result in positive and negative impacts on the English learning process.

Anxiety makes students unable to enjoy their writing. Some researchers [1],[2],[3], revealed that the process and the result of English learners' poor performance in writing are affected by anxiety as the one of the factors. Kusumaningputri et al. [4] said that the negative impact takes place when the participants cannot utilize the anxiety which the students have. The bad score is potentially received by students, included students with very low anxiety levels if their anxiety cannot be employed. They described that utilizing anxiety means the participants can change anxiety into something useful since actually anxiety can aims as a controller to attend making errors or mistakes. They concluded that if the participants are successful to get the profit of anxiety, it means anxiety suppliess a positive effect.

Regarding that case, several studies conducted by the researchers [5],[6],[7]. They showed that the level of anxiety in writing. For instance,Huwari and Al-Shboul [5] found that a high level of writing anxiety is faced by graduates learners of EFL, which the older students is less apprehensive than young doctoral students. In addition, Meng and Tseng [6] investigated anxiety in writing and academic writing practice of EFL graduates. They found that the higher level of anxiety owned by graduate students especially in writing the literature review. Meanwhile, Ariyanti [7] investigated foreign language anxiety in academic writing. She found that 
students experienced high anxiety, moderate anxiety and low anxiety. Some researchers [8], [9],[3], mentioned that anxiety is able to affect the process and students achievement in writing. Based on several multidimensional measures of anxiety, it was stated that anxiety is grouped into somatic, cognitive, and behavioral [10]. He explains that the Second Language Writing Anxiety Inventory (SLWAI) fulfills to a threedimensional conceptualization of anxiety, namely: cognitive, somatic, and avoidance behavior.

The first one type is cognitive anxiety. Any zeal in the human brain and its information processing is linked to cognitive anxiety. Cheng [10]states that cognitive anxiety points to participants' mental aspect when they face anxiety, such as negative allegations, obsession with performance, and concern about friends' perceptions. When the learners feel anxious in writing, it will transition to the negative self-connected cognition, such as "thought of abortive attempt (for example "I am not capable to finish it"), self-deprecation (for example "I am only no good at this") and avoidance (for example "I hope this was finish").

The second type is somatic. Somatic is especially about physical or body manner. Wahyuni and Umam [11] claims that somatic anxiety shows to one's perception of the psychological influences of the anxiety face, namely nervousness and tension. At times participants are feeling nervous in high tightness while they are under time-constrained and they did not find any idea. The learners who are anxious in writing a second or foreign language structure will experience somatic illnesses like sweating, shaking, increased heart rate, headache, and speedy breathing.

Then, the kinds of anxiety is avoidance behavior. Cheng [10] declares that generally experienced by second/ foreign language learners. Evasion behavior points to the behavioral aspect when the learners are anxious. Wahyuni and Umam [11] notice that avoidance anxiety is a type of anxiety where the learners avoid writing. For example, the learners did not come to the writing. This is the most dangerous kind of writing anxiety cause the learners will avert writing.

Furthermore, other researchers found types of anxiety in writing for instance [11];[4]; [4], [13]. Wahyuni and Umam [11] investigate that the writing anxiety of English students of STAIN Kediri. Kusumaningputri et al. [4] investigated second language writing anxiety of Indonesian EFL students. Hartono and Maharani [13] researched the writing anxiety of Indonesian EFL Learners. They found similar kinds of writing anxiety namely cognitive, somatic, and avoidance behavior experienced by the learnerss in their studying writing. Cognitive anxiety becomes the primary types of writing anxiety of students in writing text. However, the types of anxiety in the background of the problem need to be discussed.

Moreover,Younas et al. [14] and Rudiyanto [15] conducted researches on the cause of writing anxiety. They [14] explained that the writing anxiety found among the students of B.S. English. Meanwhile,
Rudiyanto [15] describe writing anxiety toward Indonesian EFL students in writing descriptive text. They found similar factors that the participants experience English writing anxiety namely less practice, lack of knowlodge, insufficient writing strategies, writing in time constraint. The other two causes added by Younas et al. [14], there is fear of teacher's negative comments and problems with topic choice. The points out that caused student anxiety in writing caused by the lack of knowledge of the students. Cheng [10] declares that writing anxiety in undergraduate EFL writers is related to factors namely instructional practices, personal beliefs about writing and studying to write, selfperceptions, and interpersonal menaces. Meanwhile, Masriani et al. [16] state that factors that influence learners in writing a foreign language such as; negative feedback and lack of motivation in writing. They also found that some sources of graduate - level writing anxiety in research proposal, namely: time constraints, pressure of getting good grades, professors' expectations, self-expectations regarding publishing in academic journals [16]. Meanwhile, Meng and Tseng [6] found that the cause of anxiety namely feel lack of capability to logically synthesize a plethora of prior searches to create an argument. They [6] found that higher level of anxiety in the literature review section.

However, this study focused on anxiety in writing background of the research problem. First, the researcher found the levels and types anxiety. The second, the researcherinterviewed the students to know the causes of anxiety in writing background. This study investigated students' anxiety in writing an introduction of thesis proposal at Universitas Muslim Nusantara Al-Washliyah Medan.

\section{METHOD}

This study was done on the eight-semester students at English Department of Universias Muslim Nusantara AlWashliyh, Medan. This research analysed a qualitative method. In collecting data, questionnaire and interview were used as the instruments. There were four classes in the eight semesters with a total of 120 students. There were 20 students chosen as the samples. The questionnaire was adapted from Cheng [10], consisting 22 items. Meanwhile, the interview was adapted from Brown [17] and Rezaei and Jafari [18].

Then, the data were analyzed by following some steps. The first step was using a Likert type 5 choice answer format: 1 (strongly agree); 2 (disagree); 3 (uncertain); 4 (disagree); strongly disagree (1). According to Cheng [12], Second Language Writing Anxiety Inventory (SLWAI) have three levels from high to low anxiety. A high level anxiety was shown by the total score over 65 points. A low level of anxiety was indicated bythe total score below 50 and a moderate level of anxiety indicated ascorebetween 50 to 64. After the researcher found the levels and types of anxiety of each student, a semi-structured interview is collected. Then students selected to interview who get scores high; moderate; and low. 


\section{FINDING AND DISCUSSION Research Finding}

The Level of students' anxiety in writing introduction of thesis proposal

This part describes the data and result of students' level of anxiety in writing introduction of thesis proposals. The data was collected from the eightsemester students at UMN-AW Medan in the academic year 2017/2018. The results showed that the students' anxiety was categorized into three different levels in writing thesis proposals namely high, moderate, and low anxiety. These levels are presented in Table 1 as follows:

Table I. Students' Level Anxiety in writing background of research proposal

\begin{tabular}{|c|c|c|c|}
\hline Level & Number & Minimum & Maximum \\
\hline $\begin{array}{c}\text { High } \\
\text { Anxiety }\end{array}$ & 12 & 67 & 89 \\
\hline $\begin{array}{c}\text { Moderate } \\
\text { Anxiety }\end{array}$ & 6 & 57 & 67 \\
\hline $\begin{array}{c}\text { Low } \\
\text { Anxiety }\end{array}$ & 2 & 44 & 49 \\
\hline Total & 20 & & \\
\hline
\end{tabular}

Table I displays that from 20 participants, the scores in this study ranged from 44 to 89 . There are 12 students got high writing anxiety level,withthe points of 67,69,71,74,75,76,76,80,82,87,89and 89. Moderate anxiety is gotten by 6 respondents, the points are $57,61,61,61$ and 63 and 6 . The last, low anxiety which is experienced by 2 students, the point are 44 and 49 . It can be concluded that most of the students were having high anxietyin writing thesis proposals.

The types of students' anxiety in writing background of research proposal.

Table II. The mean of each classification of writing anxiety

\begin{tabular}{|c|c|c|c|}
\hline $\begin{array}{c}\text { Classifications } \\
\text { of writing } \\
\text { anxiety }\end{array}$ & $\begin{array}{c}\text { Number } \\
\text { of } \\
\text { students }\end{array}$ & $\begin{array}{c}\text { Total } \\
\text { score }\end{array}$ & Mean \\
\hline Cognitive & 20 & 519 & 25.95 \\
\hline Somatic & 20 & 391 & 19.55 \\
\hline $\begin{array}{c}\text { Avoidance } \\
\text { behavior }\end{array}$ & 20 & 483 & 24.15 \\
\hline
\end{tabular}

From the table above, there are 3 kinds of anxiety, consist of cognitive, somatic and avoidance behavior. From the 20 students that have been chosen, the mean score of cognitive anxiety is 25.95 , somatic anxiety is 19.55 and avoidance behavior is 24.15 .

\section{Result of the interview}

The students reported causes of writing anxiety in writing introduction of thesis proposal namely; low selfconfidence, self-perception, and lack of knowledge as reflected in the statements below made by students (high, moderate and low anxiety in writing background of thesis proposal.

The students reported:

a. I am not really confident with writing an introduction especially the background of thesis proposal. I always get nervous.

b. I keep thinking that my friends are better at writing the background of thesis proposal than me.

c. I get nervous when I have not prepared in writing.

d. Before I write background, I feel anxious.

e. I feel afraid of making mistakes, such as grammar, the use of tenses,etc.

f. I feel nervous to write the introduction proposal especially in writing background.

g. I feel to compose writing the background of research problem is very hard.

\section{Discussion}

This research discovered the level, the kind and the major factors that induce writing anxiety in writing the introduction of thesis proposal among the eight-semester English students of Universitas Muslim Nusantara AlWashliyah Medan. The result of this research found that 12 students were having high anxiety in writing introduction of thesis proposal especially in writing background; 6 students experienced moderate level anxiety and the last 2 students faced low level of writing anxiety in writing background of thesis proposal.

Meanwhile, the analysis the types of anxiety in writing introduction of thesis proposal especially in background of research problem, cognitive anxiety becomes the dominants types of writing the background of thesis proposal. The mean score for cognitive anxiety is 25.95 , the mean score for somatic anxiety in the writing background is 19.55, and the next type is avoidance behavior, which has a mean score of 24.15. These results are in line with other studies conducted by[19]; [20];[21] and also[11].

Meanwhile, Rudiyanto[15] describe that English writing anxiety toward Indonesian EFL students in writing descriptive text. They found similar causes that the participant face English writing anxiety namely inadequate writing practice, linguistic problems, inadequate writing strategies, limited time. The other two causes added by Younas [14], there is fear of teacher's negative comments and problems with topic choice. He points out that student anxiety in composing effected by the poor of abilities of students.

Furthermore, the dominant causes of writing anxiety in introduction of thesis proposal especially in writing background of research problems are discoragement, self-perception, and poor of information. However, previous research from Rungruangthum [22] found that the cause of anxiety in writing research paper, namely time constrains, confulsion of getting well grades, lectures' expectations, self-expectations, relathing publishing in academic journals. Meanwhile,Meng and Tseng [6]found that the main effect of anxiety namely perceived poor of capability to make an argument especially in literature review of 
related theory.

According to Kara [1], anxiety is pondered as one of the effectss that trigger the activities of learning. Anxiety makes students unable to perform the best in writing especially background of research problems. Writing anxiety is a serious problem gazed by most EFL/ESL students cause their writing in the first language is dissimilar than writing in a foreign language [5].

It is concluded that writing anxiety is a feeling which the students perceive anxiety to write background of the research problem. The students must write a thesis proposal, but they tend to be anxious to write background of research problems. It makes them anxious to write what they want and think.

\section{CONCLUSION}

This research purposed to investigate the student's anxiety in writing introduction of thesis proposal and its source among EFL students' at the English Department of Universitas Muslim Nusantara Al-Washliyah Medan . Based on the result and discussion of the study on level, types and cause anxiety in writing introduction of thesis proposal, it is concluded there are three students' levels namely high anxiety (12 students), moderate anxiety (6 students), and low anxiety ( 2 students). The types of anxiety found in this research namely cognitive, somatic, and avoidance behavior. The dominant type found in writing background of research problems is cognitive anxiety. The cognitive anxiety average is 25.95 . The causes of anxiety in writing background of research problem such as: low self-confidence, self-perception, and lack of knowledge.

\section{AUTHORS' CONTRIBUTIONS}

By using this description, it is expected that further researches can be conducted by other researchers about anxiety on students especially in writing introduction of thesis proposal. The future research may be investigated by using some methods to cope with it or help the students how to overcome writing anxiety.

\section{ACKNOWLEDGEMENTS}

A great appreciation for the lecturer who gives many contributions in finishing this study especially the lecturer at English Department of Muslim Nusantara Al_Washliyah Medan. I would you like also thank to my contributors Dr. Hamzah, M.A., M.M. and Dr. Havid Ardi, S.Pd., M.Hum.

\section{REFERENCES}

[1] S. Kara, "Writing anxiety: A case study on students' reasons for anxiety in writingclasses.," Anadolu Üniversitesi, Türkiye., vol. 5, no. 103-111, 2013.

[2] M. Fareed, A. Ashraf, and M. Bilal, "Learners' Writing Skills: Problems, Factors, and Suggestions.," J. Educ. Soc. Sci., vol. 4, no. 2. p. 81-92., 2016.
[3] R. Toba, W. N. Noor, and L. O. Sanu, "The Current Issues of Indonesian EFL Students' Writing Skills: Ability, Problem, and Reason in Writing Comparison and Contrast Essay," Din. Ilmu, vol. 19(1), pp. 57-73.2019.

[4] R. Kusumaningputri. T. A. Ningsih, and W. Wisasongko, "Second Language Writing Anxiety of Indonesian EFL Students," Ling. Cult., no. 12(4), pp. 357-362, 2018.

[5] I. F. Huwari and Y. Al-Shboul, "Student's strategies to reduce writing apprehension (A case study on Zarqa University)," Mediterr. J. Soc. Sci., no. 7(3 S1), pp. 283-283, 2016.

[6] Z. Meng and L. Tseng, "Writing anxiety and EFL graduates' academic writing practices: A case study on two EFL graduate students' learning to write thesis proposals," pp. 8-9, 2013.

[7] A. Ariyanti, "Foreign language anxiety in academic writing. DinamikaIlmu: Jumal Pendidikan," Din. Ilmu J. Pendidik., vol. 17, no. 1, pp. 143-152.

[8] S. Kara. "Writing anxiety: A case study on students reasons for anxiety in writing classes. AnadoluÜniversitesi. Türkiye." Anadolu J. Educ. Sci. Int., no. 5, pp. 103-111. 2013.

[9] M. Fareed, A. Ashraf. and M. Bilal. "ESL learners' writing skills: Problems, factors, and suggestions." J. Educ. Soc. Sci., no. 4(2), pp. 81-92, 2016.

[10] Y. Cheng, "Students' writing anxicty: Sources and implications. English Teaching \& Learning," Mediterr. J. Soc. Sci., vol. 29, no. 2, pp. 41-62, 2004.

[11] S. Wahyuni and M. K. Umam, "An analysis on writing anxiety of Indonesian EFL college learners.," JEELS (Journal English Educ. Linguist. Stud., vol. 4, no. 1, pp. 105-128., 2017.

[12] Y. Cheng, "EFL Students' writing anxiety: Sources and implications," English Teach Learn., no. 29(2), pp. 41-62, 2004.

[13] H. Hartono and M. M: Maharani, "English Writing Anxiety and the Writing Problems of Indonesia EFL LearnersIn 2nd Social and Humaniora Research Symposium (So Res 2019)," Atl. Press, pp. 513-517, 2020.

[14] M. Younas et al., "Exploring the causes of writing anxiety: A case of BS English students." Lang. India, vol. 14, no. 8, pp. 197 208, 2014.

[15] M. Rudiyanto. "English writing anxiety toward Indonesian EFL leamers: A descriptive study." Interak. J. Kependidikan. no. 12(2), 2017.

[16] Masriani, E., M. Mukhaiyar, and D. Wahyuni., "Writing anxiety and writing strategies by English department students of universitas Negeri Padang," Ling. Didakt. J. Bhs. Dan Pembelajaran Bhs., vol. 12, no. 1, pp. 76-85.

[17] H. D. Brown, The principle of language teaching and learning. New York: Pearson Longman, 2007.

[18] M. Rezaei and M. Jafari, "Investigating the levels, types, and causes of writing anxiety among Iranian EFL students: a mixed-method design.," Procedia Soc. Behav. Sci., vol. 98, pp. 1545-1554.2014. 
[19] D. Y. Chan and G. Wu, "A Study of Foreign Language Anxiety of EFL Elementary School Students in Taipei Country. National Taipei County Teacher Collage," vol. 17, no. 2, pp. 287-320, 2004.

[20] M. Rezai and M. Jafari, "Investigating the levels, types, and causes of writing anxiety among Iranian EFL students: a mixed-method design.," vol. 98, pp. 1545-1554. 2014. [Online]. Available: https://doi.org/10.1016/j.sbspro.2014.03.577.

[21] H. Zhang., A Study on ESL Writing Anxiety among Chinese English Major Effects and Coping Strategies For ESL Writing Anxiety.Kristiansan University of Sweden.

[22] M. Rungruangthum, "Writing anxiety: EFL postgraduate students writing research papers in English. Journal of studies in the English Language, 6 . 